\title{
Association between anemia and frailty in 13,175 community-dwelling adults aged 50 years and older in China
}

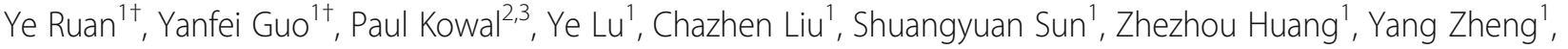 \\ Wenjing Wang ${ }^{1}$, Gan $\mathrm{Li}^{4}$, Yan Shi ${ }^{1 *}$ and Fan $\mathrm{Wu}^{1,5^{*}}$
}

\begin{abstract}
Background: Anemia and frailty contribute to poor health outcomes in older adults; however, most current research in lower income countries has concentrated on anemia or frailty alone rather than in combination. The aim of the present study was to investigate the association between anemia and frailty in community-dwelling adults aged 50 years and older in China.

Methods: The study population was sourced from the 2007/10 SAGE China Wave 1. Anemia was defined as hemoglobin less than $13 \mathrm{~g} / \mathrm{dL}$ for men and less than $12 \mathrm{~g} / \mathrm{dL}$ for women. A Frailty Index (FI) was compiled to assess frailty. The association between anemia and frailty was evaluated using a 2-level hierarchical logistic model.

Results: The prevalence of anemia was 31.0\% (95\%Cl: 28.4, 33.8\%) and frailty 14.7\% (95\%Cl: 13.5, 16.0\%). In the univariate regression model, presence of anemia was significantly associated with frailty $(O R=1.62,95 \% \mathrm{Cl}: 1.39,1.90)$ and the effect remained consistent after adjusting for various potential confounding factors including age, gender, residence, education, household wealth, fruit and vegetable intake, tobacco use, alcohol comsumption and physical activity (adjusted $\mathrm{OR}=1.31,95 \%$ Cl:1.09, 1.57). Each $1 \mathrm{~g} / \mathrm{dL}$ increase in hemoglobin concentration was associated with $4 \%$ decrease in the odds of frailty after adjusting for several confounding variables (adjusted OR=0.96, 95\% Cl: 0.93, 0.99).

Conclusion: Anemia and low hemoglobin concentrations were significantly associated with frailty. Therefore, health care professionals caring for older adults should increase screening, assessment of causes and treatment of anemia as one method of avoiding, delaying or even reversing frailty.
\end{abstract}

Keywords: Hemoglobin, Anemia, Frailty index, Ageing, China

\section{Background}

China has a rapidly growing older adult population along with increasing life expectancy from 44.6 years in 1950 to 75.3 years in 2015 , and is projected to reach almost 80 years by 2050 [1]. With ageing populations comes shifts in disease burdens, typically towards chronic non-communicable diseases. Low haemoglobin $(\mathrm{Hb})$ in older adults increases the risk for a number of poor health outcomes, with anemia defined as hemoglobin less than $13 \mathrm{~g} / \mathrm{dL}$ for men and less than 12

\footnotetext{
* Correspondence: shiyan@scdc.sh.cn; wufan@shmu.edu.cn

${ }^{\dagger}$ Ye Ruan and Yanfei Guo contributed equally to this work.

${ }^{1}$ Shanghai Municipal Centre for Disease Control and Prevention (Shanghai

CDC), Shanghai, People's Republic of China

Full list of author information is available at the end of the article
}

$\mathrm{g} / \mathrm{dL}$ for women [2], increasing the levels of fatigue, cognitive decline and weakening muscle strength [3]. These same factors also contribute to frailty in older adults.

Frailty is a geriatric syndrome that increases vulnerability to stressors and leads to risk of negative outcomes such as falls, dependency, hospitalization and death [4]. While many tools were available to ascertain frailty, two tools were commonly used [5]. Rockwood defined frailty in terms of the accumulation of deficits (Frailty Index, FI), and generally including 30-40 variables [6]. Fried suggested a frailty phenotype identified by the presence of three or more of five components (unintentional weight loss, weakness, poor endurance and energy, slowness and low physical activity) [7]. The prevalence of

(c) The Author(s). 2019 Open Access This article is distributed under the terms of the Creative Commons Attribution 4.0 International License (http://creativecommons.org/licenses/by/4.0/), which permits unrestricted use, distribution, and reproduction in any medium, provided you give appropriate credit to the original author(s) and the source, provide a link to the Creative Commons license, and indicate if changes were made. The Creative Commons Public Domain Dedication waiver (http://creativecommons.org/publicdomain/zero/1.0/) applies to the data made available in this article, unless otherwise stated. 
frailty varied from 4 to $59.1 \%$ with different assessment and geographic region [8].

The burden imposed by the co-occurrence of anemia and frailty in older age posed a potential challenge for healthcare systems worldwide. A recent meta-analysis estimated that older persons with anemia had more than double the odds of frailty, although with conflicting results for the two longitudinal studies ( $2-5$ years followup) that assessed the association between anemia and frailty [9]. Many of the studies that contributed to these estimates were focused on high-income countries, and used the phenotype criteria [7] to define frailty. To our knowledge, there have been no large representative studies to assess the relationship between anemia and frailty in older community-dwelling population in China.

The aim of the present study was to investigate the association between anemia and frailty in communitydwelling adults aged 50 years and older from the World Health Organization Study on global AGEing and adult health (SAGE) China Wave 1.

\section{Methods}

\section{Study population and design}

SAGE was a longitudinal cohort study of ageing and older adults in six low- and middle-income countries (China, Ghana, India, Mexico, Russian Federation and South Africa) [10]. The study population was sourced from SAGE China Wave 1 from 2007 to 2010, using a probability sampling design and a five-stage cluster sampling strategy [11]. SAGE China Wave 1 contacted 1642 individual respondents aged $18-49$ years and 13,367 respondents aged $50+$ years. The response rate for the individual questionnaire was $98 \%$, and a final total sample size of 13,175 for this analysis.

SAGE was approved by the World Health Organization's Ethical Review Board (RPC146), and local approval by the ethics review committee of the Chinese Center for Disease Control and Prevention (approval notice 200, 601). Each respondent signed informed consent.

\section{Measures \\ Anemia}

Blood hemoglobin concentrations were derived from dry blood spot samples and examined using standardized enzyme-linked immunosorbent assay (ELISA) techniques at the laboratory in Shanghai Municipal Centre for Disease Control and Prevention. The World Health Organization's (WHO) definition of anemia was used: $\mathrm{Hb}$ less than $13 \mathrm{~g} / \mathrm{dL}$ for men and less than $12 \mathrm{~g} / \mathrm{dL}$ for women [2].

\section{Frailty}

Frailty was defined using the deficit accumulation approach. A Frailty Index (FI) was generated as the proportion of deficits present out of 40 variables available in the SAGE database, including self-rated health, 9 medically diagnosed conditions, 4 medical symptoms, 13 functional activities assessments, 10 activities of daily living (ADLs), body mass index (BMI, calculated as weight/ height $\left.{ }^{2}\left(\mathrm{~kg} / \mathrm{m}^{2}\right)\right)$, grip strength and gait speed [12]. Individual scores ranged from 0 (no deficits) to 1 (highest level of deficits in all variables). The FI cut-off value of 0.2 was defined as approaching a frail state [12].

\section{Other covariates}

SAGE used a standardized survey instrument to collect sociodemographic information and behavioral risk factors based on the WHO STEPwise approach to Surveillance (WHO STEPS, WHO 2005). Socio-demographic variables included age, sex, education, rural/urban residence, and household wealth. All respondents were categorized into four age groups: 50-59, 60-69,70-79 and 80 years or older. The international classification scheme was used to classify the level of education into six categories (No formal education, less than primary, primary school completed, secondary school completed, high school completed, college completed and above) [13]. The household wealth quintiles were generated using an asset-based approach, ranging from quintile1 (Q1, lowest) to quintile 5 (Q5, highest) [14]. Alcohol and tobacco consumption, low physical activity level and insufficient fruit and vegetable intake were included as common non-communicable disease risk factors. The individuals were classified into four groups (never smoker, not current smokers, current smokers (not daily) and current daily smokers) on the basis of the form and amount of tobacco use. Alcohol consumption had four groups: never drinker, non-heavy drinkers, infrequent heavy drinkers and frequent heavy drinkers by calculating the number of alcoholic drinks consumed within a given week. The Global Physical Activity Questionnaire (GPAQ) was used to generate three categories of physical activity: low, moderate and high levels [15]. Insufficient fruit and vegetable intake was defined as eating fruit and vegetable less than five servings (equivalent to at least $400 \mathrm{~g}$ per day) [16].

\section{Statistical methods}

Statistic analyses were conducted using STATA SE version 14.1 (Stata Corp, College Station, TX). The population prevalence of anemia and frailty was calculated by using normalized weights. Weights were based on selection probability, non-response, and post-stratification adjustments. A 2-level hierarchical logistic model was used to evaluate the association between anemia and frailty using STATA command "melogit". We also included hemoglobin concentration as a continuous variable in the model 3 and 4 to see if there was an 
association between hemoglobin concentration and frailty. Covariates of interest included age, gender, residence, education, household wealth, fruit and vegetable intake, tobacco use, alcohol comsumption and physical activity. $P<0.05$ from two-sided statistical tests was considered statistically significant.

\section{Results}

The sociodemographic characteristics of samples were shown in Table 1. A total of 13,175 individuals aged 50 and older were included in the analysis. The proportion of women $(50.2 \%)$ was higher than men $(49.8 \%)$ in the study, with small sex differences by age groups. The overall mean age was 62.6 years (SE 0.2). The majority of the respondents were between 50 and 59 years old (44.9\%), nearly half of all respondents (47.3\%) lived in an urban area. Fifty-eight percent had completed primary school or higher. The prevalences of lowest and highest wealth quintile were 16.3 and $21.8 \%$ respectively.

The mean $\mathrm{Hb}$ level was $13.3 \pm 3.0 \mathrm{~g} / \mathrm{dL}$, being $14.0 \pm 3.0 \mathrm{~g} / \mathrm{dL}$ in men and $12.8 \pm 2.8 \mathrm{~g} / \mathrm{dL}$ in women respectively (2633 of 13,175 blood samples were missing).
Overall prevalence of anemia was 31.0\% (95\% CI: 28.4, $33.8 \%$ )(Table 2). By gender, $31.7 \%$ of men and $30.3 \%$ of women were found to be anemic $(\mathrm{F}=3.103, P=0.048)$. The prevalence of anemia among rural dwelling respondents $(19.4 \%)$ was lower than in urban areas $(46.3 \%)(\mathrm{F}=$ 76.318, $P<0.001)$. Anemia prevalence was higher in older age groups. Higher wealth individuals had higher anemia rates, reaching $39.7 \%$ (95\% CI: 34.1, $45.5 \%$ ) in the richest group. In contrast, the prevalence of anemia decreased $(\mathrm{F}=4.656, \quad \mathrm{P}<0.001)$ at higher levels of education.

Frailty prevalence was $14.7 \%$ (95\%CI: 13.5, 16.0\%), being higher in women $(17.4 \%)$ than men $(11.9 \%)(\mathrm{F}=$ 52.933, $\mathrm{P}<0.001$ ) (Table 3$)$. The $80+$ age group had the highest prevalence of frailty (41.2\%). Compared with urban respondents, rural dwellers had higher levels of frailty (15.6\%). Lower education and wealth levels were associated with higher frailty $(\mathrm{P}<0.001)$.

Table 4 shows the associations between anemia and frailty for all respondents. In the univariate regression model (model 1), presence of anemia was significantly associated with frailty $(\mathrm{OR}=1.62,95 \% \mathrm{CI}: 1.39,1.90)$ and the effect attenuated only slightly after adjusting

Table 1 Sociodemographic characteristics of the study population, by sex, SAGE China Wave 1

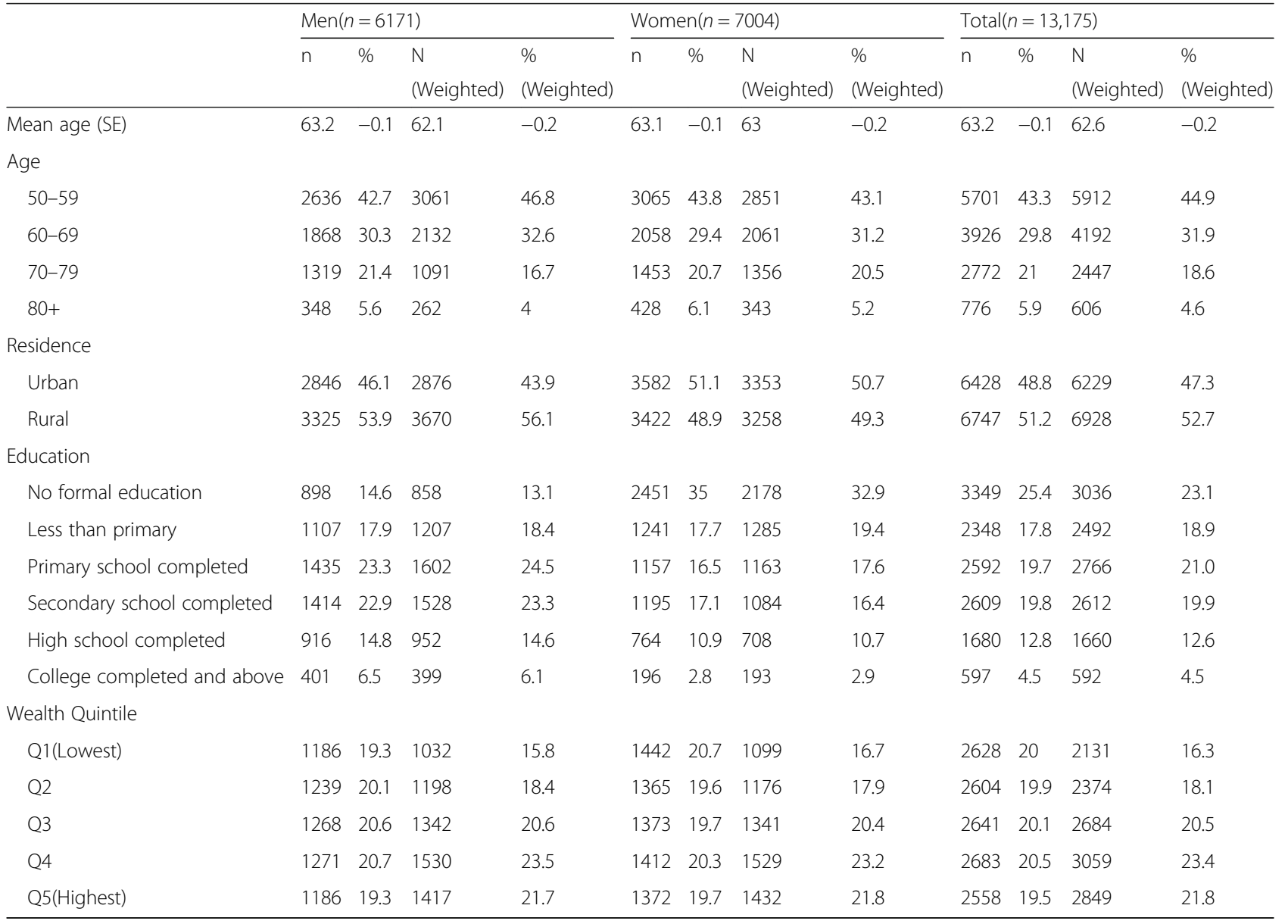


Table 2 Prevalence of anemia ${ }^{\mathrm{a}}$ among adults aged 50 years and older, SAGE China Wave 1

\begin{tabular}{|c|c|c|c|c|c|c|}
\hline & \multicolumn{2}{|c|}{ Men $(n=5044)$} & \multicolumn{2}{|c|}{ Women $(n=5482)$} & \multicolumn{2}{|c|}{ Total $(n=10,526)$} \\
\hline & $\%$ & $95 \% \mathrm{Cl}$ & $\%$ & $95 \% \mathrm{Cl}$ & $\%$ & $95 \% \mathrm{Cl}$ \\
\hline Total & 31.7 & {$[29.0,34.5]$} & 30.3 & {$[27.3,33.5]$} & 31.0 & {$[28.4,33.8]$} \\
\hline \multicolumn{7}{|l|}{ Age } \\
\hline $50-59$ & 26.5 & {$[22.7,30.7]$} & 29.4 & {$[26.2,32.8]$} & 27.9 & {$[24.7,31.2]$} \\
\hline $60-69$ & 30.2 & {$[26.2,34.4]$} & 29.8 & {$[26.2,33.7]$} & 30.0 & {$[26.8,33.5]$} \\
\hline 70-79 & 38.5 & {$[33.4,43.8]$} & 37.8 & {$[33.2,42.5]$} & 38.1 & {$[33.7,42.7]$} \\
\hline $80+$ & 43.8 & {$[36.2,51.7]$} & 38.9 & {$[31.1,47.4]$} & 41.2 & {$[35.5,47.1]$} \\
\hline $\mathrm{F}$ & 9.628 & & 3.231 & & 4.221 & \\
\hline$P$ & $<0.001$ & & 0.006 & & 0.002 & \\
\hline \multicolumn{7}{|l|}{ Residence } \\
\hline Urban & 48.5 & {$[42.6,54.5]$} & 44.3 & {$[39.9,48.8]$} & 46.3 & {$[41.5,51.2]$} \\
\hline Rural & 18.3 & {$[15.7,21.2]$} & 20.7 & {$[17.6,24.0]$} & 19.4 & {$[16.8,22.2]$} \\
\hline $\mathrm{F}$ & 94.443 & & 59.367 & & 76.318 & \\
\hline$P$ & $<0.001$ & & $<0.001$ & & $<0.001$ & \\
\hline \multicolumn{7}{|l|}{ Education } \\
\hline No formal education & 33.0 & {$[28.0,38.4]$} & 35.4 & {$[31.6,39.5]$} & 34.7 & {$[31.2,38.5]$} \\
\hline Less than primary & 27.1 & {$[22.3,32.6]$} & 29.9 & {$[25.8,34.3]$} & 28.5 & {$[24.6,32.7]$} \\
\hline Primary school completed & 29.8 & {$[24.8,35.3]$} & 33.7 & {$[29.6,38.2]$} & 31.4 & {$[27.3,35.7]$} \\
\hline Secondary school completed & 32.9 & {$[27.9,38.4]$} & 28.5 & {$[23.6,33.9]$} & 31.2 & {$[26.8,35.9]$} \\
\hline High school completed & 29.4 & {$[20.5,40.4]$} & 27.5 & {$[21.2,34.8]$} & 28.6 & {$[21.5,37.1]$} \\
\hline College completed and above & 29.5 & {$[17.8,44.8]$} & 20.0 & {$[12.2,31.0]$} & 26.1 & {$[16.2,39.1]$} \\
\hline $\mathrm{F}$ & 0.515 & & 3.862 & & 4.656 & \\
\hline$P$ & 0.653 & & $<0.001$ & & $<0.001$ & \\
\hline \multicolumn{7}{|l|}{ Wealth Quintile } \\
\hline Q1(Lowest) & 26.0 & {$[21.9,30.6]$} & 33.5 & {$[28.8,38.6]$} & 29.8 & {$[26.0,33.9]$} \\
\hline Q2 & 29.0 & {$[25.1,33.3]$} & 31.0 & {$[26.3,36.1]$} & 30.0 & {$[26.1,34.2]$} \\
\hline Q3 & 29.0 & {$[24.7,33.6]$} & 30.4 & {$[26.6,34.5]$} & 29.7 & {$[26.2,33.4]$} \\
\hline Q4 & 25.9 & {$[21.2,31.2]$} & 28.2 & {$[24.4,32.2]$} & 27.0 & {$[23.1,31.2]$} \\
\hline Q5(Highest) & 42.3 & {$[35.3,49.7]$} & 36.9 & {$[32.1,42.0]$} & 39.7 & {$[34.1,45.5]$} \\
\hline $\mathrm{F}$ & 8.557 & & 4.624 & & 7.400 & \\
\hline$P$ & $<0.001$ & & $<0.001$ & & $<0.001$ & \\
\hline
\end{tabular}

${ }^{a}$ Weighted results

for various potential confounding factors including age, gender, residence, education, household wealth, fruit and vegetable intake, tobacco use, alcohol comsumption and physical activity (model 2) (adjusted $\mathrm{OR}=1.31$, 95\% CI:1.09, 1.57). Further, we included hemoglobin concentration in the model 3 and 4 to examine the associations, and found each $1 \mathrm{~g} / \mathrm{dL}$ increase in hemoglobin concentration was associated with $4 \%$ decrease in the odds of frailty after adjusting for age, gender, residence, education, household wealth, fruit and vegetable intake, tobacco use, alcohol comsumption and physical activity (adjusted OR = 0.96, 95\% CI: 0.93, 0.99).

\section{Discussion}

This study reported the prevalences of anemia and frailty and the two conditions combined in a large population of older Chinese adults. The prevalences of both conditions were higher at older ages and in individuals with lower education levels. In addition, anemia was significantly associated with frailty, where each $1 \mathrm{~g} / \mathrm{dL}$ increase in hemoglobin concentration was related with $4 \%$ decrease in the odds of frailty after adjusting for several variables. As far as we know, this was the first paper addressing the association between anemia and frailty among community-dwelling adults aged 50 years and older in China. 
Table 3 Prevalence of frailty ${ }^{a}$ among adults aged 50 years and older, SAGE China Wave 1

\begin{tabular}{|c|c|c|c|c|c|c|}
\hline & \multicolumn{2}{|c|}{ Men $(n=6124)$} & \multicolumn{2}{|c|}{ Women $(n=6949)$} & \multicolumn{2}{|c|}{ Total $(n=13,070)$} \\
\hline & $\%$ & $95 \% \mathrm{Cl}$ & $\%$ & $95 \% \mathrm{Cl}$ & $\%$ & $95 \% \mathrm{Cl}$ \\
\hline Total & 11.9 & {$[10.6,13.3]$} & 17.4 & {$[15.9,19.1]$} & 14.7 & {$[13.5,16.0]$} \\
\hline \multicolumn{7}{|l|}{ Age } \\
\hline $50-59$ & 5.7 & {$[4.6,7.1]$} & 10.0 & {$[8.5,11.8]$} & 7.8 & {$[6.7,9.0]$} \\
\hline $60-69$ & 12.9 & {$[11.1,14.9]$} & 17.2 & {$[14.9,19.8]$} & 15.0 & {$[13.4,16.8]$} \\
\hline 70-79 & 21.3 & {$[18.3,24.6]$} & 27.1 & {$[23.9,30.6]$} & 24.5 & {$[22.1,27.0]$} \\
\hline $80+$ & 38.0 & {$[31.5,45.1]$} & 43.6 & {$[36.9,50.6]$} & 41.2 & {$[36.3,46.3]$} \\
\hline $\mathrm{F}$ & 84.699 & & 65.848 & & 135.252 & \\
\hline$P$ & $<0.001$ & & $<0.001$ & & $<0.001$ & \\
\hline \multicolumn{7}{|l|}{ Residence } \\
\hline Urban & 11.4 & {$[9.3,13.8]$} & 15.6 & {$[13.5,18.0]$} & 13.7 & {$[11.8,15.8]$} \\
\hline Rural & 12.3 & {$[10.8,14.0]$} & 19.3 & {$[17.2,21.6]$} & 15.6 & {$[14.2,17.2]$} \\
\hline $\mathrm{F}$ & 0.487 & & 5.272 & & 2.281 & \\
\hline$P$ & 0.487 & & 0.024 & & 0.134 & \\
\hline \multicolumn{7}{|l|}{ Education } \\
\hline No formal education & 19.1 & {$[16.0,22.7]$} & 25.4 & {$[23.1,28.0]$} & 23.6 & {$[21.6,25.9]$} \\
\hline Less than primary & 12.4 & {$[10.1,15.0]$} & 17.4 & {$[14.2,21.1]$} & 15.0 & {$[12.8,17.4]$} \\
\hline Primary school completed & 13.2 & {$[11.0,15.8]$} & 14.1 & {$[11.7,17.0]$} & 13.6 & {$[11.7,15.8]$} \\
\hline Secondary school completed & 8.9 & {$[6.9,11.4]$} & 11.2 & {$[8.8,14.1]$} & 9.8 & {$[8.2,11.8]$} \\
\hline High school completed & 8.8 & {$[6.7,11.5]$} & 10.4 & {$[7.7,13.8]$} & 9.5 & {$[7.7,11.6]$} \\
\hline College completed and above & 8.8 & {$[5.5,13.7]$} & 8.3 & {$[4.7,14.2]$} & 8.6 & {$[5.5,13.3]$} \\
\hline $\mathrm{F}$ & 8.183 & & 19.881 & & 29.388 & \\
\hline$P$ & $<0.001$ & & $<0.001$ & & $<0.001$ & \\
\hline \multicolumn{7}{|l|}{ Wealth Quintile } \\
\hline Q1(Lowest) & 17.8 & {$[15.1,20.9]$} & 23.0 & {$[20.2,26.1]$} & 20.5 & {$[18.3,22.9]$} \\
\hline Q2 & 15.5 & {$[12.8,18.7]$} & 21.1 & {$[18.1,24.3]$} & 18.3 & {$[16.1,20.7]$} \\
\hline Q3 & 12.4 & {$[10.5,14.7]$} & 19.5 & {$[17.1,22.3]$} & 16.0 & {$[14.3,17.8]$} \\
\hline Q4 & 10.0 & {$[8.1,12.2]$} & 14.5 & {$[12.1,17.3]$} & 12.2 & {$[10.4,14.3]$} \\
\hline Q5(Highest) & 5.5 & {$[3.7,8.0]$} & 10.3 & {$[7.8,13.5]$} & 7.9 & {$[6.1,10.2]$} \\
\hline $\mathrm{F}$ & 16.200 & & 14.101 & & 24.866 & \\
\hline$P$ & $<0.001$ & & $<0.001$ & & $<0.001$ & \\
\hline
\end{tabular}

${ }^{\mathrm{a}}$ Weighted results

While estimates of anemia prevalence differed considerably, with reported prevalence ranging from 2.9 to $61 \%$ in older men and from 3.3 to $41 \%$ in older women [17], the prevalence was generally higher in men than in women and increased with advancing age [17, 18]. Anemia prevalence was $14.1 \%$ for men and $10.2 \%$ for women aged 65 and older in the US National Health and Nutrition Examination Survey (NHANES 20132016) [19]. An Australian epidemiologic study had anemia estimates of $14.6 \%$ among men aged $70+$ years [20]. Thirty-eight percent of community-dwelling people aged 60 years and older had anemia in a small study in India [21]. Likewise, 38.1\% of older adults had anemia in the Singapore Longitudinal Ageing Studies (SLAS) [22].
Our analyses indicated that the prevalence of anemia was $31.0 \%$ (95\%CI: 28.4-33.8\%) in China, which was higher in men, older people, lower levels of education, and those lived in urban area and with higher wealth, being inverse of some results among older Mexican adults [23]. Considering hemoglobin is an indicator for malnutrition in older population, the contrast may be due to the different distribution of missing data among income groups in our research. If those with missing data disproportionately fell into the higher/lower income group, the prevalence of anemia will be underestimated/ overestimated. In addition, the different population, sampling programs and hemoglobin test methods may also contribute to the difference between these studies. 
Table 4 Odds ratios (95\% confidence intervals) for frailty, unadjusted and adjusted by covariates

\begin{tabular}{|c|c|c|c|c|}
\hline \multirow[t]{2}{*}{ Variables } & Model1 & Model2 & Model3 & Model4 \\
\hline & OR $(95 \% C l)$ & Adjusted OR (95\%Cl) & OR $(95 \% C l)$ & Adjusted OR (95\%Cl) \\
\hline Anemia & $1.62^{* *}[1.39,1.90]$ & $1.31 * *[1.09,1.57]$ & 1 & 1 \\
\hline $\mathrm{Hb}$ concentration & 1 & 1 & $0.90^{* *}[0.87,0.92]$ & $0.96^{* *}[0.93,0.99]$ \\
\hline \multicolumn{5}{|l|}{ Age } \\
\hline $50-59$ & & ref & & ref \\
\hline $60-69$ & & $1.99^{* *}[1.69,2.35]$ & & $1.98^{* *}[1.68,2.34]$ \\
\hline $70-79$ & & $3.22^{* *}[2.66,3.89]$ & & $3.19^{* *}[2.64,3.86]$ \\
\hline $80+$ & & $7.14^{* *}[5.45,9.35]$ & & $7.12^{* *}[5.43,9.33]$ \\
\hline \multicolumn{5}{|l|}{ Gender } \\
\hline Men & & ref & & ref \\
\hline Women & & $1.23^{*}[1.03,1.46]$ & & $1.18[0.99,1.41]$ \\
\hline \multicolumn{5}{|l|}{ Residence } \\
\hline Urban & & ref & & ref \\
\hline Rural & & $0.92[0.62,1.37]$ & & $0.93[0.62,1.37]$ \\
\hline \multicolumn{5}{|l|}{ Education } \\
\hline No formal education & & ref & & ref \\
\hline Less than primary & & $0.75^{* *}[0.62,0.91]$ & & $0.75^{* *}[0.62,0.92]$ \\
\hline Primary school completed & & $0.68^{* *}[0.56,0.83]$ & & $0.69^{* *}[0.56,0.84]$ \\
\hline Secondary school completed & & $0.71^{* *}[0.56,0.90]$ & & $0.72^{* *}[0.57,0.91]$ \\
\hline High school completed & & $0.66^{* *}[0.50,0.87]$ & & $0.66^{* *}[0.50,0.88]$ \\
\hline College completed and above & & $0.59^{*}[0.39,0.89]$ & & $0.60^{*}[0.40,0.91]$ \\
\hline \multicolumn{5}{|l|}{ Wealth quintile } \\
\hline Q1(Lowest) & & ref & & ref \\
\hline Q2 & & $0.87[0.72,1.06]$ & & $0.87[0.72,1.05]$ \\
\hline Q3 & & $0.72^{* *}[0.59,0.89]$ & & $0.72 * *[0.58,0.89]$ \\
\hline Q4 & & $0.69^{* *}[0.55,0.86]$ & & $0.68^{* *}[0.58,0.89]$ \\
\hline Q5(Highest) & & $0.59^{* *}[0.44,0.78]$ & & $0.58^{* *}[0.44,0.77]$ \\
\hline \multicolumn{5}{|l|}{ Fruit and vegetable intake } \\
\hline Insufficient & & ref & & ref \\
\hline Sufficient & & $0.66^{* *}[0.57,0.77]$ & & $0.66^{* *}[0.57,0.76]$ \\
\hline \multicolumn{5}{|l|}{ Alcohol consumption } \\
\hline Never drinker & & ref & & ref \\
\hline Non-heavy drinkers & & $0.78^{*}[0.63,0.97]$ & & $0.79 *[0.63,0.97]$ \\
\hline Infrequent heavy drinkers & & $1.36[0.72,2.59]$ & & $1.36[0.71,2.59]$ \\
\hline Frequent heavy drinkers & & $0.75[0.51,1.09]$ & & $0.76[0.52,1.10]$ \\
\hline \multicolumn{5}{|l|}{ Tobacco use } \\
\hline Never smoker & & ref & & ref \\
\hline Not current smoke & & $1.12[0.80,1.56]$ & & $1.11[0.80,1.56]$ \\
\hline Smoker, not daily & & $0.97[0.59,1.60]$ & & $0.98[0.59,1.62]$ \\
\hline Current daily smoker & & $0.93[0.76,1.13]$ & & $0.93[0.76,1.14]$ \\
\hline \multicolumn{5}{|l|}{ Physical activity } \\
\hline Lower level & & ref & & ref \\
\hline Moderate level & & $0.54^{* *}[0.46,0.64]$ & & $0.54^{* *}[0.46,0.63]$ \\
\hline High level & & $0.36^{* *}[0.30,0.42]$ & & $0.36^{* *}[0.30,0.42]$ \\
\hline Constant & & $0.23^{* *}[0.15,0.36]$ & & $0.46^{*}[0.25,0.85]$ \\
\hline
\end{tabular}


Attention to the measurement and impact of frailty in older age has increased substantially over the past decade. For example, the overall weighted prevalence of frailty was $9.9 \%$ in the community-dwelling older population (60+ years) derived from the China Comprehensive Geriatric Assessment Study (CCGAS), based on the Comprehensive Geriatric Assessment Frailty Index [24]. The physical frailty phenotype approach was used in an analysis of the China Health and Retirement Longitudinal Study (CHARLS), resulting in $7 \%$ of adults aged 60 years or older being classified as frail [25]. In our research, $14.7 \%$ (95\%CI: $13.5-16.0 \%)$ of communitydwelling residents aged $50^{+}$years were frail by using FI assessment, higher than the two studies mentioned which use somewhat different frailty criteria.

Anemia reduces the oxygen-carrying capacity, which can result in tissue hypoxia and lead to a number of poor outcomes, including reduced submaximal and maximal aerobic capacity, failing muscle strength, cognitive impairment and development of frailty [26-28], which related to vulnerability and some negative outcomes. Several previous studies have examined the interaction between anemia and frailty among older people in high income countries. A case-control study in Baltimore (USA) firstly explored the relationship between anemia and frailty, showing an inverse correlation between interleukin-6 (IL-6) and hemoglobin or hematocrit in the frail group, suggesting that frail subjects have evidence of inflammation and lower hemoglobin and Hematocrit levels [29]. Data from the Women's Health and Aging Studies (WHAS) I and II found that mildly low and low-normal hemoglobin levels were associated with increased frailty, and the risk of frailty increased at statistically significant levels for anemia adjusted for age, race, and education [30, 31]. Another cross-sectional and longitudinal study in older Australian men also suggested that anemia may contribute to the development of frailty [20]. Recent studies including both older men and women indicated that older anemic adults were more likely to be frail, with the association between lower levels of hemoglobin and number of frailty criteria showing dose-response effect [32-34]. However, another contrasting result suggested having anemia contributed to a weak but significantly lower chance of worsening frailty [35]. In our study, we used 40 variables to construct a Frailty Index and observed that both anemia and lower concentrations of hemoglobin were associated with frailty.

Some studies have suggested that age-associated chronic inflammation is an explanatory factor in the relationship between anemia and frailty. In older adults, anemia and frailty may share a pathophysiological pathway with chronic inflammatory processes, resulting from immunosenescence-associated changes and increased oxidative stress [36-38]. Gabriele [39] described a close connection between inflammaging, anemia, and frailty, where comorbidities and inflammaging contribute to anemia of chronic inflammation (ACI), which was the most frequent type of anemia in older adults. Considering the etiopathogenetic mechanisms of inflammation, some interventions such as dietetic approach and physical exercise that can moderate oxidative stress and chronic inflammation may prevent anemia, frailty and their negative impact on functional performance and quality of life. Another study reported that a high intake of dietary total antioxidant capacity (TAC) was inversely related with frailty, and the intake of green tea, vegetable and fruits which contributed to TAC was also associated with lower odds of frailty [40]. Our results also indicated sufficient intake of vegetables and fruit and moderate to high levels of physical exercise had protective effects against frailty.

There were a few limitations in our study. Firstly, we used cross-sectional data from SAGE China Wave 1, it cannot provide causal direction in the relationship between anemia and frailty. Results from SAGE China Waves 2 and 3 may provide an opportunity to examine the direction of this relationship we identified. Secondly, we used self-report for some items to construct Frailty Index, which may be influenced by recall bias, although self-reported health questions were widely applied in population studies. Thirdly, the missing data for haemoglobin may have also contributed to selection bias. We analyzed the distribution of the missing data of $\mathrm{Hb}$ and found that total of missing values were randomly distributed across five income groups, but there were significant differences between rural and urban across the income groups, that might be the reason why higher wealth individuals had higher anemia rates. However, our study was based on a large, national probability and representative sample of older adults of both genders in China. Furthermore, the results indicated a quantitative relationship between hemoglobin concentration and frailty.

\section{Conclusions}

In conclusion, anemia and frailty were prevalent in China dwelling adults aged 50 years and older, and we also found that anemia and lower levels of hemoglobin concentration were significantly associated with frailty. Therefore, health care professionals caring for older adults may want to improve their recognition and treatment of anemia in their patient populations. Attention at the primary care level may reduce this risk for frailty, disability, hospitalization and mortality. This way, effective policies, early screening and health interventions can be employed for avoiding, delaying or even reversing frailty in a rapidly growing population in China. 


\section{Abbreviations}

ACl: Anemia of chronic inflammation; ADLs: Activities of daily living; BMI: Body mass index; CCGAS: China Comprehensive Geriatric Assessment Study; CHARLS: China Health and Retirement Longitudinal Study; ELISA: Enzyme-linked immunosorbent assay; Fl: Frailty Index; GPAQ: Global Physical Activity Questionnaire; Hb: Haemoglobin; IL-6: Interleukin-6; NHANES: National Health and Nutrition Examination Survey; SAGE: Study on global AGEing and adult health; SLAS: Singapore Longitudinal Ageing Studies; TAC: Total antioxidant capacity; WHAS: Women's Health and Aging Studies; WHO: World Health Organization

\section{Acknowledgements}

The authors wish to express their appreciation to all respondents for their time, and all involved provincial and local centers for disease control and prevention (CDC), and the more than 160 field interviewers for their support and hard work.

\section{Authors' contributions}

FW, PK, YFG and YZ designed, implemented the conduct of this study. YL, CZL and WJW examined the blood hemoglobin concentrations. YR, YFG and YS conceived of the analysis, contributed to the statistical analyses and drafted the manuscript. SYS, ZZH and GL contributed to the editing of initial draft. All authors read and approved the final manuscript.

\section{Funding}

This work was supported by the US National Institutes on Aging through Interagency Agreements [OGHA 04034785; YA1323-08-CN-0020; Y1-AG-100501] and through a research grant (R01-AG034479) in the design and conducting of the study, data collection and analysis. It was also supported by Shanghai Municipal Health Commission, Shanghai, China [201840118; 20174Y0147] in interpretation of data and writing the manuscript.

\section{Availability of data and materials}

The datasets supporting the conclusions of this article are available upon request in the website of WHO (http://apps.who.int/healthinfo/systems/ surveydata/index.php/catalog/sage).

\section{Ethics approval and consent to participate}

SAGE was approved by the World Health Organization's Ethical Review Board (RPC146), and local approval by the ethics review committee of the Chinese Center for Disease Control and Prevention (approval notice 200601). Each respondent signed informed consent.

\section{Consent for publication}

Not applicable.

\section{Competing interests}

The authors declare that they have no competing interests.

\section{Author details}

'Shanghai Municipal Centre for Disease Control and Prevention (Shanghai (DC), Shanghai, People's Republic of China. ${ }^{2}$ World Health Organization, Geneva, Switzerland. ${ }^{3}$ Research Institute for Health Sciences, Chiang Mai University, Chiang Mai, Thailand. ${ }^{4}$ School of public health, Shanghai Jiaotong university, Shanghai, People's Republic of China. ${ }^{5}$ Shanghai Medical College, Fudan University, Shanghai, People's Republic of China.

\section{Received: 2 July 2019 Accepted: 31 October 2019}

\section{Published online: 04 December 2019}

\section{References}

1. World Health Organization. China country assessment report on ageing and health. https://www.who.int/ageing/publications/china-country-assessment/ en/. Accessed Nov 212018.

2. World Health Organization. Haemoglobin concentration for the diagnosis of anaemia and assessment of severity. Available at http://www.who.int/vmnis/ indicators/haemoglobin.pdf. Accessed Nov 212018.

3. Roy CN. Anemia in frailty. Clin Geriatr Med. 2011;27(1):67-78. https://doi.org/ 10.1016/j.cger.2010.08.005.
4. Morley JE, Vellas B, van Kan GA, Anker SD, Bauer JM, Bernabei R, et al. Frailty consensus: a call to action. J Am Med Dir Assoc. 2013;14(6):392-7. https:// doi.org/10.1016/j.jamda.2013.03.022.

5. Dent E, Kowal $\mathrm{P}$, Hoogendijk EO. Frailty measurement in research and clinical practice: a review. Eur J Intern Med. 2016;31:3-10. https://doi.org/10. 1016/j.ejim.2016.03.007.

6. Rockwood K, Mitnitski A. Frailty in relation to the accumulation of deficits. J Gerontol A Biol Sci Med Sci. 2007;62(7):722-7.

7. Fried LP, Tangen CM, Walston J, Newman AB, Hirsch C, Gottdiener J, et al. Frailty in older adults: evidence for a phenotype. J Gerontol A Biol Sci Med Sci. 2001;56(3):146-56.

8. Collard RM, Han B, Schoevers RA, Oude Voshaar RC. Prevalence of frailty in community-dwelling older persons: a systematic review. J Am Geriatr Soc. 2012;60(8):1487-92. https://doi.org/10.1111/j.1532-5415.2012.04054.x.

9. Palmer K, Vetrano DL, Marengoni A, Tummolo AM, Villani ER, Acampora N, et al. The relationship between Anaemia and frailty: a systematic review and meta-analysis of observational studies. J Nutr Health Aging. 2018;22(8):96574. https://doi.org/10.1007/s12603-018-1049-x.

10. Kowal P, Chatterji S, Naidoo N, Biritwum R, Fan W, Lopez Ridaura R, et al. Data resource profile: the World Health Organization study on global AGEing and adult health (SAGE). Int J Epidemiol. 2012;41(6):1639-49. https:// doi.org/10.1093/ije/dys210.

11. Wu F, Guo Y, Kowal P, Jiang Y, Yu M, Li X, et al. Prevalence of major chronic conditions among older Chinese adults: the study on global AGEing and adult health (SAGE) wave 1. PLoS One. 2013;8(9):e74176. https://doi.org/10. 1371/journal.pone.0074176.

12. Biritwum RB, Minicuci N, Yawson AE, Theou O, Mensah GP, Naidoo N, et al. Prevalence of and factors associated with frailty and disability in older adults from China, Ghana, India, Mexico, Russia and South Africa. Maturitas. 2016;91:8-18. https://doi.org/10.1016/j.maturitas.2016.05.012.

13. United Nations Educational Scientific and Cultural Organization. International standard classification of education (ISCED). 1997.

14. Ferguson BD, Tandon A, Gakidou E, Murray CJL. Estimating permanent income using asset and indicator variables. In: Evans DE, Murray $\mathrm{CJ}$, editors. Health systems performance assessment debates, methods and empiricism. Geneva: World Health Organization; 2003. p. 747-60.

15. World Health Organization. Global Physical Activity Questionnaire (GPAQ) Analysis Guide. Available at: https://www.who.int/ncds/surveillance/steps/ resources/GPAQ_Analysis_Guide.pdf. Accessed Nov 152018.

16. World Health Organization. Diet, nutrition and the prevention of chronic diseases. Report of a joint WHO/FAO expert consultation. In: WHO Technical Report Series No 916. Geneva: World Health Organization; 2003.

17. Beghé C, Wilson A, Ershler WB. Prevalence and outcomes of anemia in geriatrics: a systematic review of the literature. Am J Med. 2004;116(Suppl 7A):3S-10S. https://doi.org/10.1016/j.amjmed.2003.12.009.

18. Gaskell H, Derry S, Andrew Moore R, McQuay HJ. Prevalence of anaemia in older persons: systematic review. BMC Geriatr. 2008;8:1-8. https://doi.org/10. 1186/1471-2318-8-1

19. Seitz AE, Eberhardt MS, Lukacs SL. Anemia prevalence and trends in adults aged 65 and older: U.S. National Health and Nutrition Examination Survey: 2001-2004 to 2013-2016. J Am Geriatr Soc. 2018;66(12):2431-2. https://doi. org/10.1111/jgs. 15530 .

20. Hirani V, Naganathan V, Blyth F, Le Couteur DG, Kelly P, Handelsman DJ, et al. Cross-sectional and longitudinal associations between Anemia and frailty in older Australian men: the Concord health and aging in men project. J Am Med Dir Assoc. 2015;16(7):614-20. https://doi.org/10.1016/j. jamda.2015.02.014.

21. Paul SS, Abraham VJ. How healthy is our geriatric population? A community-based cross-sectional study. J Family Med Prim Care. 2015;4(2): 221-5. https://doi.org/10.4103/2249-4863.154653.

22. Ng TP, Feng L, Nyunt MS, Larbi A, Yap KB. Frailty in older persons: multisystem risk factors and the frailty risk index (FRI). J Am Med Dir Assoc. 2014;15(9):635-42. https://doi.org/10.1016/.jamda.2014.03.008.

23. Samper-Ternent R, Michaels-Obregon A, Wong R. Coexistence of obesity and Anemia in older Mexican adults. Ageing Int. 2011;37(1):104-17. https:// doi.org/10.1007/s12126-011-9135-y.

24. Ma L, Tang Z, Zhang L, Sun F, Li Y, Chan P. Prevalence of frailty and associated factors in the community-dwelling population of China. J Am Geriatr Soc. 2017;66(3):559-64. https://doi.org/10.1111/jgs.15214.

25. Wu C, Smit E, Xue QL, Odden MC. Prevalence and correlates of frailty among community-dwelling Chinese older adults: the China health and 
retirement longitudinal study. J Gerontol A Biol Sci Med Sci. 2017;73(1):1028. https://doi.org/10.1093/gerona/gl×098.

26. Artz AS. Anemia and the frail elderly. Semin Hematol. 2008;45(4):261-6. https://doi.org/10.1053/j.seminhematol.2008.06.002.

27. Kim SW, Han HS, Jung HW, Kim Kl, Hwang DW, Kang SB, et al. Multidimensional frailty score for the prediction of postoperative mortality risk. JAMA Surg. 2014;149(7):633-40. https://doi.org/10.1001/jamasurg.2014.241.

28. Silva JC, Moraes ZV, Silva C, Mazon Sde B, Guariento ME, Neri AL, et al. Understanding red blood cell parameters in the context of the frailty phenotype: interpretations of the FIBRA (frailty in Brazilian seniors) study. Arch Gerontol Geriatr. 2014;59(3):636-41. https://doi.org/10.1016/j.archger. 2014.07.014

29. Leng S, Chaves P, Koenig K, Walston J. Serum interleukin-6 and hemoglobin as physiological correlates in the geriatric syndrome of frailty: a pilot study. J Am Geriatr Soc. 2002;50(7):1268-71.

30. Chaves PH, Semba RD, Leng SX, Woodman RC, Ferrucci L, Guralnik JM, et al. Impact of anemia and cardiovascular disease on frailty status of communitydwelling older women: the Women's health and aging studies I and II. J Gerontol A Biol Sci Med Sci. 2005;60(6):729-35.

31. Chang SS, Weiss CO, Xue QL, Fried LP. Patterns of comorbid inflammatory diseases in frail older women: the Women's Health and Aging Studies I and II. J Gerontol A Biol Sci Med Sci, 2010 65(4):407-413 doi:https://doi.org/10. 1093/gerona/glp181

32. Pires Corona L, Drumond Andrade FC, de Oliveira Duarte YA, Lebrao ML. The relationship between anemia, hemoglobin concentration and frailty in Brazilian older adults. J Nutr Health Aging. 2015;19(9):935-40. https://doi. org/10.1007/s12603-015-0502-3.

33. Liotta G, O'Caoimh R, Gilardi F, Proietti MG, Rocco G, Alvaro R, et al. Assessment of frailty in community-dwelling older adults residents in the Lazio region (Italy): a model to plan regional community-based services. Arch Gerontol Geriatr. 2017;68:1-7. https://doi.org/10.1016/j.archger.2016.08.004.

34. Nadruz W Jr, Kitzman D, Windham BG, Kucharska-Newton A, Butler K, Palta $P$, et al. Cardiovascular dysfunction and frailty among older adults in the community: the ARIC study. J Gerontol A Biol Sci Med Sci. 2017;72(7):95864. https://doi.org/10.1093/gerona/glw199.

35. Trevisan C, Veronese N, Maggi S, Baggio G, Toffanello ED, Zambon S, et al. Factors influencing transitions between frailty states in elderly adults: the Progetto Veneto Anziani longitudinal study. J Am Geriatr Soc. 2017;65:17984. https://doi.org/10.1111/jgs.14515.

36. Chang SS, Weiss CO, Xue QL, Fried LP. Association between inflammatoryrelated disease burden and frailty: results from the Women's health and aging studies (WHAS) I and II. Arch Gerontol Geriatr. 2012;54(1):9-15. https:/ doi.org/10.1016/j.archger.2011.05.020.

37. Macciò A, Madeddu C. Management of anemia of inflammation in the elderly. Anemia. 2012;2012:563251. https://doi.org/10.1155/2012/563251.

38. Baylis D, Bartlett DB, Patel HP, Roberts HC. Understanding how we age: insights into inflammaging. Longev Healthspan. 2013;2(1):8. https:/doi.org/ 10.1186/2046-2395-2-8

39. Röhrig G. Anemia in the frail, elderly patient. Clin Interv Aging. 2016;17(11): 319-26. https://doi.org/10.2147/CIA.S90727.

40. Kobayashi S, Asakura K, Suga H, Sasaki S. Inverse association between dietary habits with high total antioxidant capacity and prevalence of frailty among elderly Japanese women: a multicenter cross-sectional study. J Nutr Health Aging. 2014;18(9):827-39. https://doi.org/10.1007/s12603-014-0478-4.

\section{Publisher's Note}

Springer Nature remains neutral with regard to jurisdictional claims in published maps and institutional affiliations.

Ready to submit your research? Choose BMC and benefit from:
- fast, convenient online submission
- thorough peer review by experienced researchers in your field
- rapid publication on acceptance
- support for research data, including large and complex data types
- gold Open Access which fosters wider collaboration and increased citations
- maximum visibility for your research: over 100M website views per year
At BMC, research is always in progress.
Learn more biomedcentral.com/submissions

